\title{
Chagas Disease in Ecuador: Evidence for Disease Transmission in an Indigenous Population in the Amazon Region
}

\section{Martha Chico H/ ${ }^{+}$, Carlos Sandoval, Angel Guevara E, Manuel Calvopiña H, Philip J Cooper, Steve G Reed*, Ronald H Guderian}

\author{
Departamento de Investigaciones Clínicas, Hospital Vozandes, HCJB, Casilla 17-17-691, Quito, Ecuador \\ *Corixa Corp, 1124 Colombia St. 464, Seattle, WA 98104, USA
}

Two well-defined synthetic peptides TcD and $P E P_{2}$ were used in a sero-epidemiological study for the detection of Trypanosoma cruzi infections in an indigenous group in the Amazon region of Ecuador. Of the 18 communities studied along the Río Napo, province of Napo, 15 (83.3\%) were found to be positive for $\mathrm{T}$. cruzi infection. Of the 1,011 individuals examined $61(6.03 \%)$ resulted positive. A prevalence of infection of $4.8 \%$ was found in children aged 1-5 years. The prevalence of infection increased with age, with adults 50 years or older showing a maximum prevalence of $18.8 \%$. Autochthonous transmission of $\mathrm{T}$. cruzi is present among this isolated indigenous population.

Key words: Ecuador - Chagas disease - Trypanosoma cruzi - Amerindian - Amazonia

Recently, a new sylvatic focus of Chagas disease has been reported in Ecuador (Amunárriz et al. 1991). In this focus, three Triatominae were identified as potential vectors: Panstrongylus geniculatus, Rhodnius pictipes and $R$. robustus. Their feces were found to be parasitized by Trypanosoma cruzi (Amunárriz 1991). It is perceived that the disease was probably introduced into this Amazon region due to the large migration of persons from other provinces of the country, some of which are endemic for Chagas disease. However, the epidemiological characteristics of the disease in the indigenous/native population of this area is unknown. To determine the prevalence and the geographical extension of the disease and to determine whether autochthonous transmission of $T$. cruzi is occurring in the Amazon region, a seroepidemiological survey for Chagas disease was done on an indigenous population. The results of a sero-epidemiological study done on an Amazonian Quichua population, which had lived for generations in an area where acute Chagas disease has recently been documented is reported here.

\section{MATERIALS AND METHODS}

Study population - The investigation was limited to an indigenous area in the basin of the Río Napo, in the province of Napo, extending from the

${ }^{+}$Corresponding author. Fax: +593-2-447-263

Received 12 September 1996

Accepted 23 January 1997 community of Nuevo Rocafuerte to Francisco de Orellana (a distance of approximately $300 \mathrm{~km}$ ) (Fig. 1). Along the river 18 dispersed communities with a population of 2,049 inhabitants were studied. No migration to this area from other endemic regions for Chagas disease has been documented. The population consists of $85 \%$ indigenous Quichuas and $15 \%$ mestizos who have resided in the region for several generations.

Based on the up-dated census of each community studied, random samples of $50 \%$ of each of the 18 communities were selected. All relevant data were noted in a specially designed chart including all clinical data, age, sex and race of those examined. Venous blood samples were obtained from 1,011 individuals. After centrifugation, the serum was aliquoted and stored in liquid nitrogen until processed.

The study was approved by the institutional ethics committee of Hospital Vozandes as well as by the Ecuadorian Ministry of Public Health. Informed consent was obtained from all participants.

To determine the specificity of the assays used, serum samples were collected from patients infected with other diseases known to cross-react serologically with crude $T$. cruzi antigen preparations. These included 20 samples from patients with malarial infection (Plasmodium vivax); 20 samples from patients with cutaneous leishmaniasis (Leishmania panamensis); 20 samples from patients with pulmonary tuberculosis; 20 healthy subjects from the endemic area in the province of Napo; and 20 healthy subjects (Quito) from an area where there is no transmisison of $T$. cruzi. 


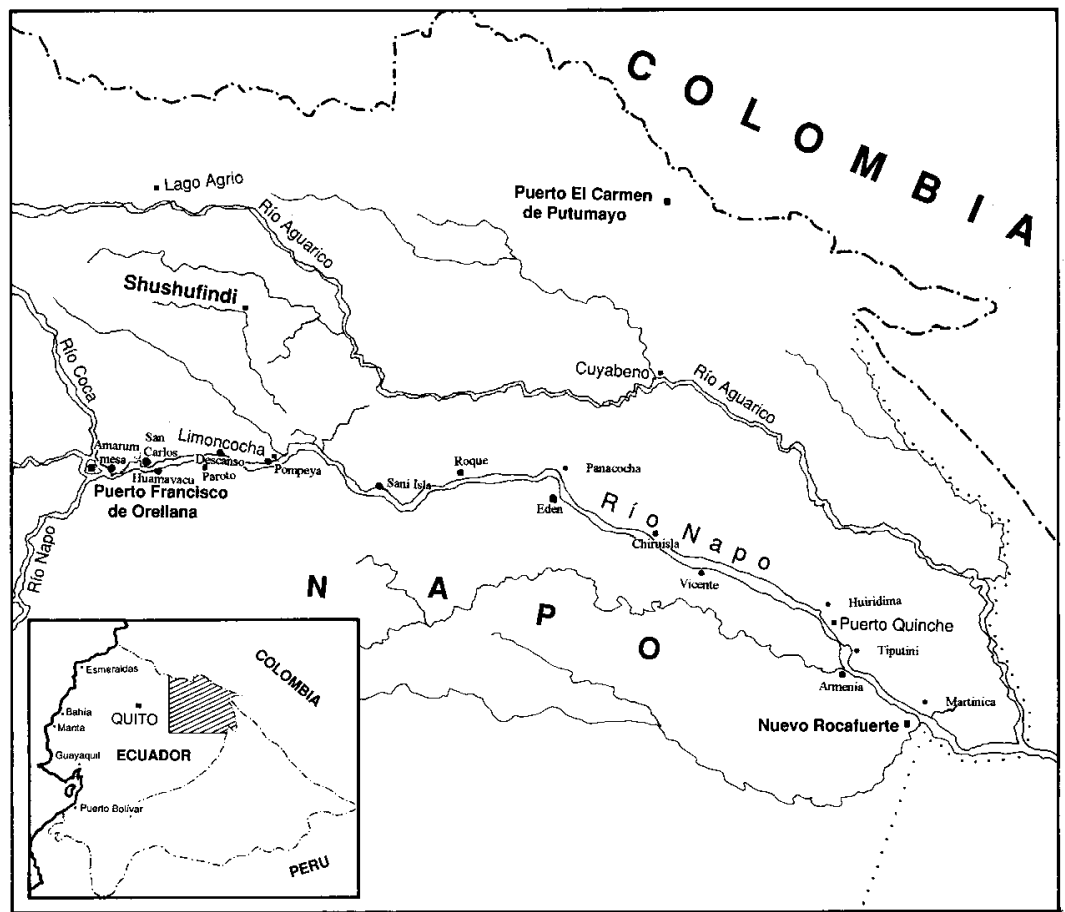

Fig. 1: map of the province of Napo, showing the location of the communities studied for Trypanosoma cruzi infection.

Crude antigen - T. cruzi epimastigotes (a Napo strain obtained from a patient with an acute infection from the Napo province) were obtained via culture. The parasites were harvested in the exponential phase and centrifuged at $2000 \mathrm{~g}$ for $25 \mathrm{~min}$ at $4^{\circ} \mathrm{C}$, washed twice in $0.01 \mathrm{M}$ phosphate buffered saline ( $\mathrm{pH} 7.2)$, and resuspended in PAPS (10 $\mathrm{mM}$ Trisma; $2 \mathrm{mM}$ EDTA $0.1 \mathrm{mg} / \mathrm{ml}$ leupeptin; 100 $\mathrm{mg} / \mathrm{ml}$ Mega-8) in order to lyse and solubilize the parasites (Reed et al. 1990). The protein content was measured using the Coomassie Blue Binding Assay (Spector 1978) and the antigen preparation was aliquoted and stored at $-70^{\circ} \mathrm{C}$ until used.

Synthetic peptides - A cocktail of two synthetic peptides, TcD and $\mathrm{PEP}_{2}$, was used. The sensitivity and specificity of these peptides for $T$. cruzi infection, the peptides amino acid sequences, and the method of synthesis have been reported previously (Burns et al. 1992, Peralta et al. 1994).

ELISA - The T. cruzi reactive IgG levels in serum of all the individuals included in this study as well as of the controls were measured by standard ELISA (Voller et al. 1976). The appropriate concentrations of antigen, sera, and anti-human serum conjugates were determined by checkerboard titration. Flat bottom plastic 96-well ELISA plates (Corning Esay Wash High Binding: Corning Laboratories, Corning, NY) were used in the ELISA assays. For crude antigen: the antigen was diluted in coating buffer $\left(15 \mathrm{mM} \mathrm{Na}_{2} \mathrm{CO}_{3} ; 28 \mathrm{mM}\right.$ $\left.\mathrm{NaHCO}_{3} ; \mathrm{pH} 9.6\right)$ and $50 \mu \mathrm{l}$ of antigen preparation $(0.1 \mu \mathrm{g} / \mathrm{ml})$ was added per well and incubated overnight at $4^{\circ} \mathrm{C}$. For the synthetic peptides: a mixture of the two peptides (TcD at $10 \mu \mathrm{g} / \mathrm{ml}$ and $\mathrm{PEP}_{2}$, at $2.5 \mu \mathrm{g} / \mathrm{ml}$ ) was diluted in coating buffer and 50 $\mu \mathrm{l}$ was added to each well and incubated overnight at $4^{\circ} \mathrm{C}$. All ELISA plates were processed as follows: $200 \mu$ l of blocking buffer [0.01 M phosphate buffered saline (pH 7.2) / 0.3\% Tween 20] was added to each well and incubated for $1 \mathrm{hr}$ at room temperature. The plates were then washed six times with wash buffer $[0.01 \mathrm{M}$ phosphate buffered saline (pH 7.2) / 0.1\% Tween 20 (Sigma)]. Unknown serum samples, positive and negative controls, were diluted 1:50 with wash buffer and $50 \mu 1$ was added to the corresponding wells. After incubation at room temperature for $30 \mathrm{~min}$, the wells were washed five times with wash buffer; then $50 \mu 1$ of protein A-horseradish peroxidase conjugate (Zymed Laboratories), diluted 1:10,000 in wash buffer, was added. The plates were incubated at room temperature for $30 \mathrm{~min}$. The wells were washed five times with wash buffer and $100 \mu \mathrm{l}$ of 2,2'-azino-di(3-ethyl-benzthiazoline sulfonate) (ABTS) substrate solution [50 $\mu 1$ of $50 \times$ ABTS, 
$50 \mu \mathrm{l}$ of $1.5 \% \mathrm{H}_{2} \mathrm{O}_{2}, 2.5 \mathrm{ml}$ of $0.1 \mathrm{M}$ citrate buffer ( $\mathrm{pH} 4.1$ ); Zymed] was added. The enzyme reaction was allowed to develop at room temperature for $30 \mathrm{~min}$ in the dark. The reaction was stopped by adding $100 \mu \mathrm{l}$ of $5 \%$ SDS and the absorbance of each well was read by an ELISA plate reader (Titertek Multiscan) at $405 \mathrm{~nm}$. For each plate, two positive and five negative control sera were included, with all tests done in duplicate. The "cut off" value was considered as the mean \pm 3 standard deviations (SD) of the absorbance values from healthy subjects from the endemic area.

\section{RESULTS}

Peptide assay - All test sera which reacted positively with the two synthetic peptides, were also positive with the crude antigen (Fig. 2). Using the synthetic peptides, none of the negative control sera were positive, but sera from one patient with tuberculosis and another individual from non-endemic area reacted positively to the crude antigen. There were six unknown serum which reacted with the crude antigen but were negative with the cocktail. These six positive sera with the crude antigen had a history of previous leishmaniasis infection and were not considered positive for Chagas disease.

Prevalence of infection - Fifteen of the 18 (83.3\%) communities studied along Río Napo were found positive for $T$. cruzi infection (Table I). The 3 negative communities were scattered along the river with positive communities located on either side. Of the 1,011 sera examined, 61 (6.03\%) were positive for $T$. cruzi infection.

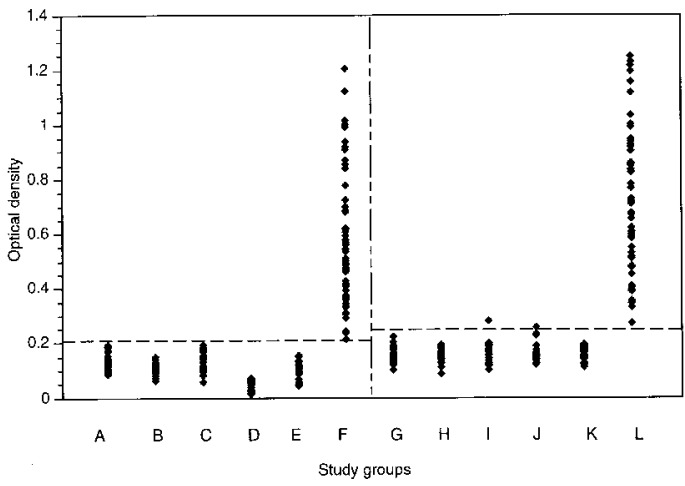

Fig. 2: scatter diagrams using the cocktail of two synthetic peptides for those infected with malaria A, leishmaniasis B, tuberculosis $\mathrm{C}$, healthly individuals from non-endemic area $\mathrm{D}$, from endemic area $\mathrm{E}$ and the unknown sera $\mathrm{F}$; and using the crude antigen for those infected with malaria G, leishmaniasis $\mathrm{H}$, tuberculosis $\mathrm{I}$, healthly individuals from non-endemic area $\mathrm{J}$, from endemic area $\mathrm{K}$ and the unknown sera $\mathrm{L}$.
Age-sex distribution - The age distribution of those positive for $T$. cruzi infection is given in Table II. Children aged 1-5 years were found infected $(4.8 \%)$. The prevalence of infection increased with age. No significant difference was noticed in the rate of infection between males $(52.4 \%)$ and females $(47.6 \%)$.

\section{TABLE I}

Prevalence of seropositivity for Trypanosoma cruzi infection in the communities studied along Río Napo, province of Napo

\begin{tabular}{lc}
\hline Communities & Prevalence $(\%)$ \\
\hline Martinica & 5.6 \\
Rocafuerte & 3.2 \\
Tiputijni & 0.0 \\
P. Quinche & 5.8 \\
Huiririma & 0.0 \\
San Vicente & 1.6 \\
Chiruisla & 7.7 \\
Eden & 7.5 \\
Panacocha & 7.5 \\
San Roque & 2.9 \\
Sanisla & 10.9 \\
Pompeya & 5.0 \\
Descanso & 0.0 \\
Paroto & 12.9 \\
Huamayacu & 3.4 \\
San Carlos & 12.5 \\
A. Mesa & 5.6 \\
S.L. Armenia & 14.2 \\
\hline
\end{tabular}

TABLE II

Prevalence of seropositivity for Trypanosoma cruzi infection according to age

\begin{tabular}{crrc}
\hline $\begin{array}{c}\text { Age } \\
\text { (years) }\end{array}$ & $\begin{array}{c}\text { Examined } \\
\text { No. }\end{array}$ & $\begin{array}{c}\text { Positive } \\
\text { No. }\end{array}$ & $\begin{array}{c}\text { Prevalence } \\
\%\end{array}$ \\
\hline $1-5$ & 42 & 2 & 4.8 \\
$6-10$ & 130 & 2 & 1.5 \\
$11-19$ & 272 & 12 & 4.4 \\
$20-29$ & 215 & 6 & 2.8 \\
$30-39$ & 148 & 7 & 4.7 \\
$40-49$ & 101 & 13 & 12.9 \\
$50-59$ & 69 & 13 & 18.8 \\
$60+$ & 34 & 6 & 17.6 \\
\hline
\end{tabular}

\section{DISCUSSION}

The finding of serological evidence for $T$. cruzi infection in a non-migratory indigenous population suggests that autochthonous transmission is occurring. The prevalence of infection was similar in all positive communities along the Río Napo. The results of this study, however, differ from the original serological survey in which the technique 
of hemo-agglutination was used and where no evidence of T. cruzi infection was found (Lazo 1985, Defranc 1987). It could be that the present method used is more sensitive for the detection of $T$. cruzi infection.

The age distribution of seropositivity for $T$. cruzi suggests that there is a constant exposure of the population to parasite transmission; seropositivity increased with age. Active autochthonous transmission is also suggested by the finding of positive children aged 1-5 years. This is further supported by recent observations which have documented acute $T$. cruzi infection in children in this area (Amunárriz et al. 1991).

The high rate of infection suggests that peridomestic rather than sylvatic transmission is most important. Adult and nymphal stages of the three sylvatic species of triatomine bug, $P$. geniculatus, $R$. pictipes and $R$. robustus have been found in the houses of these communities (unpublished observations). It seems that these sylvatic species have successfully adapted to a domestic habitat.

Of the individuals serologically positive for $T$. cruzi infection, eight had clinical evidence of cardiac involvement (Amunárriz, per. com.). Studies are in progress to determine the prevalence of chagasic cardiopathy in this area. In the province of Loja, $50.1 \%$ of those with chronic T. cruzi infection presented with cardiac abnormalities consistent with Chagas disease, $11.1 \%$ of patients presented with megaesophagus and $40.8 \%$ with megacolon (Cueva \& Romero 1987).

The first diagnostic of Chagas disease in Ecuador was made in 1929 in the province of Guayas (Defranc 1987). Since then isolated cases of both acute and chronic cases of Chagas disease have been reported in the provinces of El Oro, Guayas, Manabí, Loja and Los Rios (Lazo 1985). Still, no systematic epidemiological evaluation has been made to determine the actual status of the disease in this country. The synthetic peptide-based ELISA used in this study has proved to be both highly specific and sensitive and would be an appropriate investigational tool in sero-epidemiological surveys in other parts of Ecuador.

Strain and parasite antigen differences in the parasite, which may cause differential reactivity between endemic populations of different geographical regions, are known to exist. The finding of equivalent reactivity in this study and in another independent study conducted in Brazil (Peralta et al. 1994), suggests that this assay may also be useful in other endemic regions. The two antigens were also recognized by 25 positive sera from
Colombia (unpublished observations). Cross-reactivity with sera from leishmaniasis patients was not seen in this study, which is in agreement with a previous study reported from Brazil (Peralta et al. 1994).

The results of this study suggest that $T$. cruzi has existed for many years in this tropical zone and that it was not introduced recently by the migration of positive individuals from other provinces. As children with acute and chronic infection are routinely identified, it is apparent that active transmission of the parasite continues to occur (Amunárriz, per. com.). Serological surveys using this synthetic peptide-based assay are currently being performed in other putatively endemic regions of Ecuador and should provide important baseline information for the National Control Program for Chagas disease.

\section{REFERENCES}

Amunárriz UM 1991. Enfermedad de Chagas; primer foco amazónico, p. 27-36. In Estudios sobre Patologías Tropicales en la Amazonía Ecuatoriana, Cicame, Pompeya, Ecuador.

Amunárriz UM, Chico ME, Guderian RH 1991. Chagas' disease in Ecuador: a sylvatic focus in the Amazon Region. J Trop Med Hyg 94: 145-149.

Burns JM, Shreffler WG, Rosman DE, Sleath PR, March CJ, Reed SG 1992. Identification and synthesis of a major conserved antigenic epitope of Trypanosoma cruzi. Proc Natl Acad Sci 89: 1239-1243.

Cueva IO, Romero SR 1987. Estudio epidemiológico de la enfermedad de Chagas en la provincia de Loja, p.151-161. In Los Problemas de Salud en el Ecuador 1987. Dirección Nacional del Seguro Social Campesino.

Defranc M 1987. Prevalencia de la Enfermedad de Chagas en el Ecuador: informe 1983-1986. Rev Ecuat Hig Med Trop 37: 13-47.

Lazo RF 1985. Ecuador, p. 413-427. In Factores Biológicos y Ecológicos en la Enfermedad de Chagas. Volume 2. OMS y Servicios Nacional del Chagas. Ministerio de Salud y Acción Social, República de Argentina.

Peralta JM, Teixeira MGM, Shreffler WG, Pereira JB, Burns JM, Sleath PR, Reed SG 1994. Serodiagnosis of Chagas' disease by enzyme-linked immunosorbent assay using two synthetic peptides as antigens. J Clin Microbiol 32: 971-974.

Reed SG, Shreffler WG, Burns JM, Scott JM, Orge MG, Ghalib HW, Siddig M, Badaro R 1990. An improved serodiagnostic procedure for visceral leishmaniasis. Am J Trop Med Hyg 43: 632-639.

Spector T 1978. Refinement of the Coomassie Blue method of protein quantitation. Anal Biochem 86: 142-146.

Voller A, Bartlett A, Bidwell DE 1976. Enzyme immunoassays for parasitic diseases. Trans $R$ Soc Trop Med Hyg 70: 98-106. 